\title{
SERC broadens its role in support of industry
}

London. The UK Science and Engineering Research Council (SERC) is to launch a major effort to support research into new industrial products and manufacturing processes. Known as the Innovative Manufacturing Initiative and run by a committee dominated by industrialists, the new scheme will have an annual budget of about $£ 30$ million (US\$45 million) for research to boost Britain's capacity for wealth creation.

The new initiative, planned for later this year, is intended both to clarify the council's role in helping industry and to strengthen its hand in anticipation of the government's forthcoming White Paper (policy document) on science and technology, which is expected to contain a major shake-up in the organization of the council.

SERC would like to separate its support for the research needed to underpin the country's industrial base from those areas of science - such as astronomy and particle physics - pursued primarily for 'cultural' reasons. It has begun to increase its support of industry-orientated research in line with a recent review of its engineering programme that recommended a greater "coincidence of purpose" between the council and industry, even at the expense of university-based research groups. Last week, for example, SERC's chairman, Sir Mark Richmond, told the House of Lords Select
Committee on Science and Technology that the council is debating whether to make grants directly to industrial scientists and not only to those working on a joint project with universities.

Any such move would be widely welcomed by industry itself, which can now apply for direct research funding only from the Department of Trade and Industry (DTI).

But universities are concerned about the proposals. They argue that allocating research grants directly to industrial research groups could undermine SERC's efforts to support the transfer of technology from the academic to the industrial world.

Richmond agrees that the new funding directions would mean reduced support for the science base "in the old-fashioned sense". Indeed, SERC has already set itself the goal of reducing total expenditure on basic research by 10 per cent over the next three years as it shifts the balance between basic and applied research from 45:55 in 1991-92 to a new goal of a 40:60 distribution.

In its corporate plan for this period, being published this week, the council also sets out a number of new developments aimed at strengthening its support for industrially relevant research. In addition to the new multidisciplinary initiative in innovative manufacturing, these will include increased involvement by industry representa- tives in "top-level matters of broad policy and programme balance" and a 'concordat' with the DTI. Later this year, SERC will begin a 'business awareness scheme' to help academic scientists to understand how their discoveries could be commercialized.

The corporate plan also reveals that the council intends to launch a pilot scheme for part-time $\mathrm{PhD}$ awards, in line with the recommendations of its recent report on postgraduate engineering education (see Nature 362, 7; 1993). And SERC has decided virtually to double its public relations budget to develop teaching materials for secondary schools and to establish visitors centres at the council's main laboratories.

Given the costs of international subscriptions, the council says it plans to study ways of reducing its contributions to the European Laboratory for Particle Physics (CERN) and the European Space Agency (ESA). According to Richmond, the council is also looking at ways of transferring funds from physics to other fundamental sciences, in particular chemistry and biology.

How much of these plans remain intact after the publication of the White Paper remains to be seen. Richmond doubts that SERC will survive in its present form but is confident that the direction in which he wants to take the council is in line with the government's thinking. David Dickson

\section{OTA panel opens inquiry into patenting of genes}

Washington. Members of a panel meeting last week for the first time to advise the US Congress on gene patenting and the human genome project believe that action is needed to protect biotechnological innovation but do not agree on what should be done. The 17-member advisory panel, formed to help the congressional Office of Technology Assessment (OTA) prepare a report on the subject, raised the possibility of restricting patents to specific uses of particular gene sequences or imposing restrictions on the time for which patents can protect them.

The OTA report was requested by Senator Edward Kennedy (Democrat, Massachusetts) and Senator Mark Hatfield (Republican, Oregon) after the international fracas that followed a decision in 1991 by the National Institutes of Health (NIH) to apply for patents on thousands of human gene sequences. Hatfield is concerned about the ethical issues raised by claims of intellectual property rights on human genes. Kennedy is thought to be seeking intellectual ammunition to protect the biotechnology industry in his home state.

The advisory panel includes Craig Venter, the former NIH official whose \$70million Institute for Genomic Research in
Maryland is proceeding with a rapid programme to identify all important human genes. An associated company, Human Genome Science Inc., aims to exploit the institute's findings commercially.

"There is an explosion of new information available", said Venter after the meeting. "The question is whether the existing patent system is set up to cope. There may be the need for a couple of legislative changes, but changing the patent laws is like opening up a Pandora's Box."

This week, Venter will announce at a Washington conference organized by $\mathrm{Na}$ ture Genetics that his institute expects to isolate and sequence "the majority of human genes" in the next 12-18 months. He promises that all information not directly exploited by Human Genome Science will be made available to outside researchers.

Tom Kiley, a California patent lawyer and director of several biotechnology companies, says that patent law already allows for the utility of a given gene to be tightly specified - provided that the patent office has sufficient resource to guard against abuse. "One way forward is to change the law", he says. "Another is to give the patent office the money to do its job properly."
There is the chance that the systematic identification and patenting of human gene sequences, together with the growing commercial involvement of biotechnology companies, will eventually lead to patents being invoked to block the work of rivals. "Congress should address the issue of research exemption in case the patent system is used to discourage innovation", he says.

Bob Cook-Deegan of the Institute of Medicine warned against an international free-for-all in pursuit of the human genome, calling it "an icon for how science is changing. Scientists are making an uncomfortable transition from their former role as knights in shining armour to a new public image as commercial mercenaries."

The OTA study coincides with an investigation by the United Nations Educational, Scienific and Cultural Organization into the human genome project. The NIH patents led to concern, especially in Britain, about the willingness of the United States to share gene-sequence information with researchers elsewhere. OTA included four non-US members on its advisory OTA panel, which will meet twice more before submitting its report in April 1994.

Colin Macilwain 